\section{Prevalence, demographic characteristics and associated risk factors of malnutrition among 0-5 aged children: a cross-sectional study from Van, eastern Turkey}

\author{
Baran Serdar Kizilyildiz, 1 \\ Bülent Sönmez, ${ }^{2}$ Kamuran Karaman, ${ }^{3}$ \\ Burhan Beger, ${ }^{4}$ Adnan Mercen, ${ }^{1}$ \\ Süleyman Alioğlu, 1 Yaşar Cesur 5 \\ 1Department of Pediatrics, Private \\ Kiziltepe Ipekyolu Hospital, Mardin; \\ 2Department of Pediatrics, Private \\ Istanbul Hospital; ${ }^{3}$ Department of \\ Pediatrics, ${ }^{4}$ Department of Pediatric \\ Surgery, ${ }^{5}$ Department of Pediatric \\ Endocrinology, Faculty of Medicine, \\ Yüzüncü Yil University,Van, Turkey
}

\section{Abstract}

Malnutrition in childhood is a dramatic indicator of poor socio-economical status worldwide. To recognize and reveal the socio-demographic features is crucial, especially for developing countries. Our aim was to investigate the prevalence and association with sociodemographic variables of malnutrition in 0-5 years old children in Van, Turkey. A total of 702 children are included in this cross-sectional study. Demographic features of subject including age, gender, family characteristics and other data were obtained. Nutritional assessment was done using anthropometric indices including weight-for-age, height-for-age, weight-for-height, head circumference and body mass index-for-age. Multivariate logistic regressions were carried out to assess malnutrition-associated factors. Prevalence of underweight, stunting and wasting were 19.7, 17.7 and $16.2 \%$, respectively. Socio-demographic variables that statistical significantly in association with malnutrition were low monthly family income, educational level and employment status of father, parental consanguinity, number of pregnancies, regular intake of vitamin D and history of prematurity. The prevalence of children with head circumference-z score $\leq-2$ SD and body mass index-for-age $\leq-2$ SD were 9.8 and $16.3 \%$, respectively. Multivariate analysis detected following risk factors for these indices; low monthly family income, history of prematurity, unemployed father and the period between pregnancies (12 years). We found that prevalence of malnutrition in the city of Van, was still higher than more developed regions of Turkey. The associated risk factors of malnutrition should be specifically interpreted by health professionals and also by government authorities that are responsible for making practical politics of public health.

\section{Introduction}

Pediatric malnutrition is a major public health problem worldwide and globally a major contributive factor to nearly $45 \%$ of all mortality in childhood. ${ }^{1-3}$ Deficits of protein, energy and micronutrients together with environmental, behavioral, biological and health-care service related factors lead to growth failure, development delay and other worse outcomes.1,3,4 Malnutrition is a chronic and extensive situation, difficult to cope typical of developing countries. On the other hand, it is usually a result of acute or chronic diseases in developed countries. ${ }^{1}$ So, as generally accepted, it can be said that the physical growth of infants and children is an indicator of health and wellness. ${ }^{5}$ Assessment of pediatric malnutrition is based on objective anthropometric measurements such as Z-score, weight-for-height (wasting index), height-for-age (stunting index), weight-for-age (underweight index), head circumference, body mass index, midupper arm circumference and skin fold thickness. However it is difficult to determine malnutrition in childhood with a single index. ${ }^{3,6}$ Recently, World Health Organization (WHO) recommended new growth standards for children under 5 years and attached more indicators (e.g. body mass index for age) to describe optimal early childhood growth.7 In addition, several investigations have been performed for testing the WHO charts in different countries, which have showed disagreements in prevalence compared with existing standards, the WHO standards generally accepted for clinical assessment of malnutrition in children worldwide. 5

Few studies have been published concerning malnutrition prevalence from Eastern Turkey, but there is a lack of data including sociodemograhic features. This paper presents recent status of malnutrition in children from Van province.

\section{Materials and Methods}

This cross-sectional study was carried out between December 2009 and February 2010 in Van city. Van province is located at the Eastern border of Turkey, neighbouring Iran. This province is the most undeveloped region of the country in respect of socioeconomical and demograhic features as mentioned in report of Turkey Demographic and Health Survey,
Correspondence: Baran Serdar Kizilyildiz, Hafiziye Mah. Türközü Sok Elçioğlu Sitesi B-blok No:17, Van, Turkey.

Tel.: +90.432 .2178101$

E-mail: baranserdar@hotmail.com

Key words: Turkey; prevalence; malnutrition; wasting syndrome; thinness.

Contributions: BSK and BS wrote the paper; KK, $\mathrm{BB}, \mathrm{AM}$ and SA have collected the data, performed statistical analysis and reviewed the literature; YC revised the article.

Conflict of interest: the authors declare no potential conflict of interest.

Received for publication: 15 July 2015

Revision received: 26 April 2016.

Accepted for publication: 27 April 2016.

This work is licensed under a Creative Commons Attribution NonCommercial 4.0 License (CC BYNC 4.0).

(c)Copyright B.S. Kizilyildiz et al., 2016

Licensee PAGEPress, Italy

Pediatric Reports 2016; 8:6112

doi:10.4081/pr.2016.6112

Hacettepe University Institute of Population Studies, 2008. Estimated total population of children under 5 -year old was 42,730 . The size of sample population to calculate prevalance was determined by using $\mathrm{n}=\mathrm{X}^{2 *} \mathrm{~N}^{*} \mathrm{P} *\left[\mathrm{ME}^{2 *}\right]$ $(\mathrm{N}-1)]+\left[\mathrm{X}^{2} * \mathrm{P} *(1-\mathrm{P})\right], \mathrm{n}=$ sample size, $\mathrm{X}^{2}=$ Chisquare for the specified confidence level at 1 degree of freedom, $\mathrm{N}=$ population size, $\mathrm{P}=p o p u$ lation proportion and $\mathrm{ME}=$ desired margin of error formula. Subjects with incomplete questionnaire and absent anthropometric measures were excluded. Subjects with a previous chronic disease and cerebral palsy were also excluded. A total of 702 children were enrolled in the study. Selection of samples based on data revealed from 17 public health centers that located in socio-economically different districts of Van city. An informed consent from the mother or legal caregiver was obtained to collect socio-demographic information by using a standardized form. All children were measured and weighed according to standard procedures by the same interviewer.

Standing height was measured in over 2 years old children using a portable adult/infant-measuring unit mountable to wall with an accuracy of $0.1 \mathrm{~cm}$. The height of children under 2 years of age was measured in supine position with a measuring board. Weight was measured by infant scale with an accuracy of $10 \mathrm{~g}$ in $0-24$ month-aged and a by ground scale with an accuracy of $100 \mathrm{~g}$ in over 2 years old. The measurement of head circumference was performed using a nonstretchable 
plastic-coated tape placed superior to the supraorbital ridge and adjusted around the occiput. Body mass index was calculated using weight in kilograms that divided by the square of height in meters. Z-Scores for weight-forheight, height-for-age and weight-for-age were calculated using WHO growth standards for spesific age groups.

Wasting, stunting and underweight were defined as $z$-scores $\leq-2$ for weight-for-height, height-for-age and weight-for-age, respectively. Z-scores for body-mass index and head circumference were calculated and malnutrition was defined if $z$-scores found under -2 . Independent variables such as age, gender, and history of prematurity were listed in Tables 1-3. Socio-economical status was determined by monthly income of each subject's family using Turkish Statistical Institute data. Monthly income under $750 \mathrm{TL}, 750-1500 \mathrm{TL}$ and above 1500 TL considered as low, intermediate and high family income, respectively. Subjects, who took daily 400 U vitamin D regularly, were considered sufficent for statistical analysis.

SPSS (Statistical Package for Social Sciences) for Windows $\mathbf{1 5 . 0}$ was used for statistically analysis. Multivariate regression analysis was used to determine the risk factors of malnutrition. Results evaluated in confidence interval as $95 \%$ and a P-value of 0.05 was considered statistically significant.

\section{Results}

Our study included a total of 702 children, 371 were male and age groups were as follows: 0-5 months ( $\mathrm{n}=192), 6-11$ months $(\mathrm{n}=123)$, 12-23 months ( $\mathrm{n}=142), 24-35$ months $(\mathrm{n}=81)$, 36-47 months ( $\mathrm{n}=61)$ and 48-60 months ( $\mathrm{n}=103$ ). According to socio-economical status; 153 subjects were in low, 329 in intermediate and 220 in high-level groups. Our results revealed that overall prevalence of underweight, stunting and wasting were $19.7 \%$ $(\mathrm{n}=138), 17.7 \%(\mathrm{n}=124)$ and $16.2 \%(\mathrm{n}=114)$, respectively. No significant relationship was seen between gender and these variables. The rate of underweight, stunting and wasting were highest at 0-5 month-old group. The prevalence of children with head circumference-z score $\leq-2 \mathrm{SD}$ and body mass index-forage $\leq$-2SD were $9.8 \%(n=69)$ and $16.3 \%$ $(\mathrm{n}=115)$, respectively. Concerning all anthropometric indices, the number of male subjects who had malnutrition was higher than females but the difference was not statistically significant (Table 1). Prevalence of malnutrition among children, according to various socio demographic factors, has been showed in Table 2.

Logistic regression analysis revealed that wasting was statistically significant in association with low socio-economical status, educational level of father and employment status of father. Also, the risk of underweight among children with the following features was more likely than children without them: history of prematurity, low monthly family income, second-degree parent consanguinity and educational level of father. Regarding stunting, subjects who did not use vitamin $D$ regularly, were 2.4 times [adjusted odd ratio (AOR) $=2.4,95 \%$ confidence interval (CI): 1.2-5.1] more likely to be stunted than children who did not use. Other variables that significantly associated with stunting were low monthly family income, history of prematurity and employment status of father (Table 3 ).

In logistic regression analysis, head circumference values were significantly low in children with history of prematurity, low monthly family income and unemployed father. Malnutrition risk, according to body mass index (BMI), was also statistically significantly higher among subjects with history of prematurity and with unemployed father. This risk was increased in children whose mother had a gap of 1-2 years between pregnancies.

There were no significant relationships between malnutrition and other demographic factors including number of siblings, birth order, number of died children and/or abortions, family size, vaccination status, number of visits of health caregivers, education level, age and occupation of mother, existence of family insurance and maternal smoking (data not shown). Results of the logistic regression of both anthropometric indexes are shown in Table 3.

\section{Discussion}

In terminology of nutrition disorders exists a slight confusion. The term, Protein-energy malnutrition (PEM) has been defined as an imbalance between the supply of protein and energy and the body's demand for them to ensure optimal growth and function by $\mathrm{WHO}{ }^{4}$ On the other hand there was no consensus in defining the terms failure to thrive, failure to gain weight, undernutrition etc. and absence of a definite description of these terms results in underrecognition of prevalance, demograhic features, relationship with other disorders as well as outcomes in children.1,3,8 According to previous terminology, we used malnutrition (or PEM) term to describe the conditions that defined as underweight (low weight for age), stunting (low height for age) and wasting (low weight for height). 4

Like in other developing countries, the malnutrition of children is a major public health problem in Turkey, especially in our region. Our results has shown overall prevalence of underweight, stunting and wasting in children below 5 years of age to be 19.7, 17.7 and $16.2 \%$, respectively. These rates were higher than overall prevalence rates reported from Turkey

Table 1. Distribution of the children with malnutrition according to age and gender.

\begin{tabular}{|c|c|c|c|c|c|c|}
\hline Variable & Total & $\begin{array}{l}\text { Wasting, } \\
\text { weight-for-height } \\
\leq-2 \text { SD }(\%)\end{array}$ & $\begin{array}{l}\text { Underweight, } \\
\text { weight-for-age } \\
\leq-2 \text { SD }(\%)\end{array}$ & $\begin{array}{l}\text { Stunting, } \\
\text { height-for-age } \\
\leq-2 \text { SD (\%) }\end{array}$ & $\begin{array}{l}\text { Head circumference, } \\
\leq-2 S D(\%)\end{array}$ & $\begin{array}{c}\text { Body mass index-for-age, } \\
\leq-2 \text { SD (\%) }\end{array}$ \\
\hline \multicolumn{7}{|c|}{ Age, months } \\
\hline $0-5$ & 192 & 43 (22.3) & 49 (25.5) & $32(16.6)$ & $23(11.9)$ & $48(25)$ \\
\hline $6-11$ & 123 & 24 (19.5) & 20 (16.2) & 15 (12.1) & $7(5.6)$ & $22(17.8)$ \\
\hline $12-23$ & 142 & $20(14)$ & 25 (17.6) & $23(16.1)$ & $11(7.7)$ & $20(14)$ \\
\hline $24-35$ & 81 & $10(12.3)$ & $18(22.2)$ & $19(23.4)$ & $10(12.3)$ & $8(9.8)$ \\
\hline $36-47$ & 61 & $6(9.8)$ & $10(16.3)$ & $18(29.5)$ & $9(14.7)$ & 7 (11.4) \\
\hline $48-60$ & 103 & $11(10.6)$ & $16(15.5)$ & $17(16.5)$ & $9(8.7)$ & $10(9.7)$ \\
\hline \multicolumn{7}{|l|}{ Gender } \\
\hline Female & 331 & $50(15.1)$ & $56(16.9)$ & $54(16.3)$ & $30(9)$ & $49(14.8)$ \\
\hline Male & 371 & 64 (17.2) & $82(22.1)$ & 70 (18.8) & 39 (10.5) & 66 (17.7) \\
\hline P-value* & - & 0.859 & 0.390 & 0.893 & 0.712 & 0.434 \\
\hline Total & 702 & $114(16.2)$ & 138 (19.7) & 124 (17.7) & $69(9.8)$ & 115 (16.3) \\
\hline
\end{tabular}

*P<0.05 was considered significant. 
(underweight $2.8 \%$, stunting $10.3 \%$ and wasting $0.9 \%) .{ }^{9}$ On the other hand, Aslan et al. have reported underweight, stunting and wasting prevalence under 5 years children as 9.4, 23.4 and $4.8 \%$, respectively, in Van region in 2002. ${ }^{10}$ It can be said that, stunting prevalence has not been changed significantly during time. We thought that the distinctions in underweight and wasting ratios between our study and
Aslan et al. were due to difference of study population and recently increased migration from rural areas to city center. Similarly, different prevalence ratios of malnutrition have also been reported regarding the geographical regions in Turkey. For example in West Anatolia, stunting has been reported as 3.3\%, wasting $0.2 \%$ and underweight as $1.5 \% .{ }^{9}$ While, the prevalence was found as $10.9 \%$ for stunt- ing, $4.8 \%$ for underweight and $8.2 \%$ for wasting in children under five years in Aydin, a western city of Turkey. ${ }^{11}$ The infant mortality rate was 17 and under five mortality rate was 24 per 1000 live births in Turkey while these ratios were reported as 39 and 50 , respectively in our region. ${ }^{9}$ These data indicate the low socio-economical status in our region and explains why our malnutrition rates were

Table 2. Prevalence of wasting, underweight, stunting, head circumference under -2SD and body mass index-for-age under -2SD according to various socio demographic factors among the study population.

\begin{tabular}{|c|c|c|c|c|c|c|c|}
\hline Variable & Category & Total & $\begin{array}{l}\text { Wasting } \\
(\%)\end{array}$ & $\begin{array}{l}\text { Underweigh } \\
\text { (\%) }\end{array}$ & $\begin{array}{l}\text { Stunting } \\
(\%)\end{array}$ & 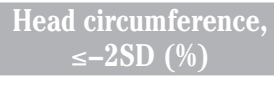 & $\begin{array}{c}\text { Body mass index-for-age, } \\
\leq-2 \text { SD }(\%)\end{array}$ \\
\hline History of prematurity & $\begin{array}{l}\text { Yes } \\
\text { No }\end{array}$ & $\begin{array}{c}47 \\
655\end{array}$ & $\begin{array}{c}14(29.7) \\
100\end{array}$ & $21(44.6)$ & $19(40.4)$ & $14(29.7)$ & $18(38.2)$ \\
\hline Regular intake of vitamin D & $\begin{array}{l}\text { Yes } \\
\text { No }\end{array}$ & $\begin{array}{l}314 \\
388 \\
\end{array}$ & $35(11.1)$ & $42(13.4)$ & $37(11.8)$ & $24(7.6)$ & $33(10.5)$ \\
\hline Vaccination status & $\begin{array}{l}\text { Partially vaccinated } \\
\text { Fully vaccinated }\end{array}$ & $\begin{array}{l}44 \\
658\end{array}$ & $9(1.4)$ & $14(2.1)$ & $9(1.4)$ & $5(11.3)$ & $12(27.2)$ \\
\hline Pregnancy intent & $\begin{array}{l}\text { Unintended } \\
\text { Intended }\end{array}$ & $\begin{array}{c}9 \\
693 \\
\end{array}$ & $1(0.14)$ & $1(0.14)$ & $1(0.14)$ & $2(22.2)$ & $2(22.2)$ \\
\hline Monthly family income & $\begin{array}{l}\text { Low } \\
\text { Intermediate } \\
\text { High }\end{array}$ & $\begin{array}{l}153 \\
329 \\
220\end{array}$ & $\begin{array}{l}30(19.6) \\
55(16.7) \\
29(13.1)\end{array}$ & $\begin{array}{l}40(26.1) \\
70(21.2) \\
29(13.1)\end{array}$ & $\begin{array}{c}36(23.5) \\
66(20) \\
23(10.4)\end{array}$ & $\begin{array}{c}16(10.4) \\
41(12.4) \\
12(5.4)\end{array}$ & $\begin{array}{l}31(20.2) \\
59(17.9) \\
25(11.3)\end{array}$ \\
\hline Number of siblings & $\begin{array}{l}1 \\
2 \\
3 \\
>3 \\
\text { Only child }\end{array}$ & $\begin{array}{c}122 \\
68 \\
133 \\
203 \\
176\end{array}$ & $\begin{array}{c}13(10.6) \\
12(17.6) \\
24(18) \\
35(21.3) \\
30(17)\end{array}$ & $\begin{array}{c}16(13.1) \\
17(25) \\
36(27) \\
36(21.9) \\
35(19.8)\end{array}$ & $\begin{array}{c}14(11.5) \\
14(20,5) \\
36(27) \\
34(20.7) \\
27(15.3)\end{array}$ & $\begin{array}{c}11(9) \\
6(8.8) \\
19(14.2) \\
16(7.8) \\
17(9.6)\end{array}$ & $\begin{array}{c}13(10.6) \\
12(17.6) \\
24(18) \\
33(16.2) \\
33(18.7)\end{array}$ \\
\hline Birth order & $\begin{array}{l}\text { First } \\
\text { After first sibling } \\
\text { Last child }\end{array}$ & $\begin{array}{l}213 \\
136 \\
353\end{array}$ & $\begin{array}{c}36(16.9) \\
12(8.8) \\
66(18.7)\end{array}$ & $\begin{array}{l}40(18.7) \\
17(12.5) \\
82(23.2)\end{array}$ & $\begin{array}{l}40(18.7) \\
20(14.7) \\
65(18.4)\end{array}$ & $\begin{array}{c}23(10.7) \\
6(4.4) \\
40(11.3)\end{array}$ & $\begin{array}{c}38(17.8) \\
8(5.8) \\
69(19.5)\end{array}$ \\
\hline Interval between pregnancies & $\begin{array}{l}<1 \text { year } \\
1-2 \text { year } \\
>2 \text { year }\end{array}$ & $\begin{array}{l}167 \\
187 \\
172 \\
\end{array}$ & $\begin{array}{l}23(13.7) \\
25(13.3) \\
26(15.1)\end{array}$ & $\begin{array}{c}33(19.7) \\
28(14.9) \\
43(25)\end{array}$ & $\begin{array}{l}39(23.3) \\
25(13.3) \\
23(13.3)\end{array}$ & $\begin{array}{c}15(8.9) \\
16(8.5) \\
18(10.4)\end{array}$ & $\begin{array}{l}21(12.5) \\
26(13.9) \\
30(17.4)\end{array}$ \\
\hline Crowded family & $\begin{array}{l}\text { Yes } \\
\text { No }\end{array}$ & $\begin{array}{l}243 \\
459\end{array}$ & $51(20.9)$ & $63(25.9)$ & $51(20.9)$ & $32(13.1)$ & $59(24.2)$ \\
\hline $\begin{array}{l}\text { Visit of health professionals } \\
\text { to home }\end{array}$ & $\begin{array}{l}\text { None } \\
1 \\
2 \\
3\end{array}$ & $\begin{array}{l}119 \\
128 \\
243 \\
212\end{array}$ & $\begin{array}{c}56(47) \\
9(7) \\
18(7.4) \\
31(14.6)\end{array}$ & $\begin{array}{c}71(59.6) \\
7(5.4) \\
21(8.6) \\
40(18.8)\end{array}$ & $\begin{array}{c}56(47) \\
5(3.9) \\
22(9) \\
42(19.8)\end{array}$ & $\begin{array}{c}29(24.3) \\
5(3.9) \\
10(4.1) \\
25(11.7)\end{array}$ & $\begin{array}{c}52(43.6) \\
7(5.4) \\
21(8.6) \\
35(16.5)\end{array}$ \\
\hline $\begin{array}{l}\text { Social security } \\
\text { (health insurance) }\end{array}$ & $\begin{array}{l}\text { Present } \\
\text { Absent }\end{array}$ & $\begin{array}{c}671 \\
31\end{array}$ & $\begin{array}{l}109(16.2) \\
5(16.1)\end{array}$ & $\begin{array}{c}133(19.8) \\
6(19.3)\end{array}$ & $\begin{array}{l}121(18) \\
4(12.9)\end{array}$ & $\begin{array}{c}59(8.7) \\
10(32.2)\end{array}$ & $\begin{array}{l}108(16) \\
7(22.5)\end{array}$ \\
\hline Educational status of mother & $\begin{array}{l}\text { Primary or less } \\
\text { Secondary } \\
\text { High } \\
\text { University }\end{array}$ & $\begin{array}{r}349 \\
235 \\
87 \\
31\end{array}$ & $\begin{array}{c}60(17.1) \\
44(18.7) \\
5(5.7) \\
58(16.1)\end{array}$ & $\begin{array}{l}82(23.4) \\
47(20) \\
4(4.6) \\
6(19.3)\end{array}$ & $\begin{array}{c}70(20) \\
41(17.4) \\
4(4.6) \\
6(19.3)\end{array}$ & $\begin{array}{c}44(12.6) \\
22(9.3) \\
2(2.2) \\
1(3.2)\end{array}$ & $\begin{array}{c}64(18.3) \\
43(18.2) \\
8(9.1) \\
0\end{array}$ \\
\hline Employment status of mother & $\begin{array}{l}\text { Employed } \\
\text { Unemployed (housewife) }\end{array}$ & $\begin{array}{c}34 \\
668\end{array}$ & $\begin{array}{c}5(14.7) \\
109(16.3)\end{array}$ & $\begin{array}{c}6(17.6) \\
133(19.9)\end{array}$ & $\begin{array}{c}6(17.6) \\
119(17.8)\end{array}$ & $\begin{array}{c}1(2.9) \\
68(10.1)\end{array}$ & $\begin{array}{c}0 \\
115(17.2)\end{array}$ \\
\hline Educational status of father & $\begin{array}{l}\text { Primary or less } \\
\text { Secondary } \\
\text { High } \\
\text { University }\end{array}$ & $\begin{array}{c}99 \\
398 \\
105 \\
100\end{array}$ & $\begin{array}{c}20(20.2) \\
73(18.3) \\
15(14.2) \\
6(6)\end{array}$ & $\begin{array}{c}28(28.2) \\
88(22.1) \\
17(16.1) \\
6(6)\end{array}$ & $\begin{array}{c}25(25.2) \\
77(19.3) \\
15(14.2) \\
8(8)\end{array}$ & $\begin{array}{c}20(20.2) \\
37(9.2) \\
8(7.6) \\
4(4)\end{array}$ & $\begin{array}{c}20(20.2) \\
76(19) \\
14(13.3) \\
4(4)\end{array}$ \\
\hline Employment status of father & $\begin{array}{l}\text { Employed } \\
\text { Unemployed }\end{array}$ & $\begin{array}{l}501 \\
201\end{array}$ & $\begin{array}{l}69(13.7) \\
45(22.3)\end{array}$ & $\begin{array}{l}85(16.9) \\
54(26.8)\end{array}$ & $\begin{array}{l}73(14.5) \\
52(25.8)\end{array}$ & $\begin{array}{c}40(7.9) \\
29(14.4)\end{array}$ & $\begin{array}{l}67(13.3) \\
48(23.8)\end{array}$ \\
\hline Parental consanguity & $\begin{array}{l}\text { Present } \\
\text { None }\end{array}$ & $\begin{array}{l}194 \\
508\end{array}$ & $\begin{array}{l}42(21.6) \\
72(14.1)\end{array}$ & $\begin{array}{l}53(27.3) \\
86(16.9)\end{array}$ & $\begin{array}{l}46(23.7) \\
79(15.5)\end{array}$ & $\begin{array}{c}26(13.4) \\
43(8.4)\end{array}$ & $\begin{array}{l}38(19.5) \\
77(15.1)\end{array}$ \\
\hline Maternal smoking & $\begin{array}{l}\text { Yes } \\
\text { No }\end{array}$ & $\begin{array}{l}112 \\
590 \\
\end{array}$ & $\begin{array}{l}22(19.6) \\
92(15.5)\end{array}$ & $\begin{array}{l}32(28.5) \\
107(18.1)\end{array}$ & $\begin{array}{l}26(23.2) \\
99(16.7)\end{array}$ & $\begin{array}{c}14(12.5) \\
55(9.3)\end{array}$ & $\begin{array}{l}19(16.9) \\
96(16.2)\end{array}$ \\
\hline
\end{tabular}


higher than mean rates of whole country.

Studies on childhood malnutrition have been reported mostly from Africa, India and other third world countries.11 In Bangladesh, $46 \%$ of the children under 5 years were underweight, $39 \%$ were stunted and $28 \%$ were wasted. ${ }^{12}$ A study from Haiti revealed that $14.8 \%$ of children under five were stunted, $15.3 \%$ were wasted, and $16.1 \%$ were underweight. 13 Manjunath et al. have reported the prevalence of underweight, stunting and wasting was $60.4,55.4$ and $43 \%$, respectively, in India. ${ }^{14}$ In addition, stunting and underweight prevalence were 44.2 and $19.1 \%$, respectively among 0-36 month-old children in Tanzania. 15 These findings are indicating the importance of both economical and social development level on prevalance of malnutrition, worldwide.

We found that low economical status was a significant risk factor of malnutrition. As mentioned before, inadequate and inappropriate food intake due to poverty is the main underlying cause of malnutrition.4,11,16 Because the severity and distribution of malnutrition depends on the political and economic situation, the level of education and sanitation, pro- duction and cultural food traditions, the availability and quality of health services and so in general monthly income of family is in close correlation with prevalance of malnutrition. ${ }^{11,16}$ A study from India has showed that, there was a twofold increase in undernutrition among children with low standard households than among those with high standards. ${ }^{4}$

Linear growth failure is the most prevalent form of malnutrition globally in children and has longer-term impact on both physical, neurodevelopmental and economic capacities. ${ }^{2}$ In a wide systematic review concerning trends in prevalence of stunting among children under 5 years old in 141 developing countries has revealed a decline in mean prevalence of moderate and severe stunting from $47.2 \%$ in 1985 to $29.9 \%$ in 2011.17 But as mentioned in the same study, although anthropometric status of children has improved during time, there were significant differences globally across geographical areas and countries. ${ }^{17}$ For example, our stunting ratio (17.7\%) was lower than in Asia (31.3\%) but higher than in South America (13.8\%). ${ }^{18}$ But in Salmas district in Iran, which is the neighboured region to Van, the preva- lence of stunting was $7.3 \%$ in 2011.6 These findings indicate the importance of local data concerning stunting to determine proper socio-economical politics for improving nutritional status of children.

The highest rates of stunting, underweight and wasting were in 0-5-month-old group in our study. Ergin et al. reported that stunting prevalance was higher in 12-23-month-old group and they suggested the fact of stopping breast-feeding earlier than the 24 months and difficulties in providing adequate and safe food as a cause of this finding. ${ }^{11}$ In addition, in a big cross-sectional study from Iran which consisted of nearly 70,000 children under 5 years of age, has shown that the highest rate of both stunting, underweight and wasting were observed at 48-59-months-age group and the authors have mentioned that high rate of breastfeeding among Iranian infants could result in low prevalence rates of malnutrition among infants than other age groups. ${ }^{19}$

Some studies from different countries reported a significant relationship between gender and malnutrition. A study from Iran has reported higher prevalence of stunting in

Table 3. Results of the logistic regression analysis of variables, which are significantly related to wasting, underweight, stunting, body mass index and head circumference among 0-5 year old children.

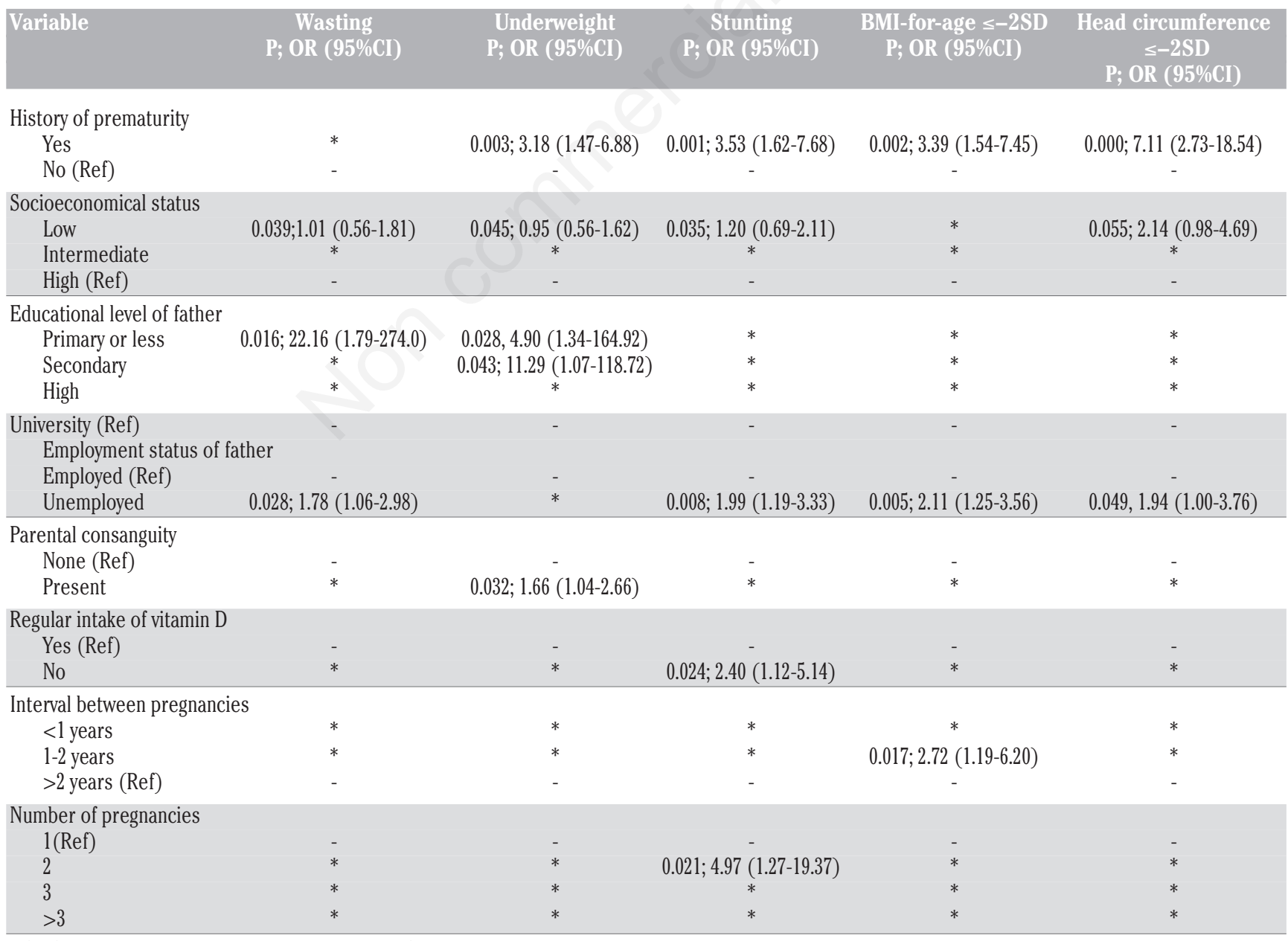

Ref=reference category; *results which were not statistically significant. 
males compared to female children; however, underweight and wasting have not significantly related with gender. ${ }^{20}$ But another study from a different region of Iran, has shown significant higher rates of wasting and stunting in girls, while no statistical difference in respect of underweight. ${ }^{19}$ Bhutia et al. mentioned that severe underweight was higher for girls than boys and, as an interesting result, the median duration of breastfeeding was 2 months longer for males than females in India. ${ }^{4}$ In contrast, Jiang et al. have reported that girls had a lower risk of becoming stunted than boys. ${ }^{18}$ In our study, there was not a significant relationship between malnutrition and gender.

Multivariate analysis of our results revealed that there was a statistically significant correlation between regular intake of vitamin $\mathrm{D}$ and stunting. Micronutrient deficiencies (especially iron, iodine, zinc and vitamin A, C, D and B) affect nearly 2 billion people worldwide and are major public health problems in developing countries. ${ }^{16}$ Vitamin D deficiency has been found in association with both skeletal and nonskletal (cardiovascular disease, certain cancers, cognitive decline, autoimmunity and allergy) poor consequences in childhood that each of them is a contributive factor for malnutrition. ${ }^{21}$ Likely with our results, these findings indicates the crucial role of vitamin D in optimal growth and development of children.

Our results have shown that the occupation and educational status of fathers were in a close relationship with prevalence of malnutrition. Previous studies have reported different results concerning this association. Kavosi $e t$ al. did not find a significant relationship between children's nutritional status and father's education level in Iran. ${ }^{20}$ In additon, there were no statistically association between father's education level or working status and malnutrition in Malaysia.22 As Ergin et al., mentioned before, father education level becomes more important than mother's in developing countries like Turkey, where the females' education level is low, ${ }^{11}$ we suggested that the fact of traditional male dominance in family economy and crowded home population might be a significant contributing factor in high rates of malnutrition prevalence.

Weight-for-age index cannot distinguish between current or past energy deficit. Similarly, height-for-age is an index of cumulative past energy deficit but cannot show current energy intake. While, BMI is an index of current energy deficit because it is based on current weight and current height of children but it can not differentiate between adiposity (fat mass) and muscularity (lean mass).23,24 In additon it has been proposed that as a index of current energy deficit, early detection of low BMI for age can be a marker for future stunting, while once stunting has occurred, it is vir- tually irreversible. ${ }^{24}$ In our study, BMI has successfully detected all of the children at the same time who also determined as malnoushired using weight-for-height index. However Ramachandran et al. have mentioned that, the median and -2SD values for BMI-forage index of Indian children were lower than WHO-2006 standards in the first month of life and also, the median of Indian children was higher from WHO standards by three months, we thought that BMI-for-age is a useful screening parameter in children but further investigations are needed for local settings like our country. 24

Prematurity was found as a global risk factor for malnutrition in our study. However, the ideal growth pattern of preterm infants remains undefined and catch-up growth timing could differ among premature babies, there are specific growth charts for determining the growth status of the premature infant based on the WHO recommendations. ${ }^{25,26}$ In addition, recent advances in neonatal care have resulted in improved survival of very and/or extremely low birth weight neonates and it has been reported that nearly $75 \%$ of such infants remained as underweight and stunted, almost 50\% having microcephaly and wasting at 1 year of corrected age. 27

\section{Conclusions}

Prevalence of malnutrition among underfive children in Van city was relatively high in respect of western regions of Turkey. The risk factors of malnutrition in childhood are well described worldwide, but to minimize their influence on malnutrition are duty of both health professionals, public authorities, educational institutions and also civil society organizations.

\section{Limitations}

Present study had some limitations. Firstly, we performed this study in an urban area and we did not determine whether the subjects were born in or came from a rural area before study period. Secondly, as a cause of acute malnutrition, we did not investigate the acute illness history, especially recent infections such as diarrheae or pneumonia in wasted children. We also did not evaluate the maternal nutritional status, which is directly in correlation with nutritional status of children.

\section{Compliance with ethical standards}

All procedures performed in studies involving human participants were in accordance with the ethical standards of the institutional and/or national research committee and with the 1964 Helsinki declaration and its later amendments or comparable ethical standards.

\section{References}

1. Becker PJ, Nieman Carney L, Corkins MR, et al. Consensus statement of the academy of nutrition and dietetics/american society for parenteral and enteral nutrition: indicators recommended for the identification and documentation of pediatric malnutrition (undernutrition). J Acad Nutr Diet 2014;114: 1988-2000.

2. Prendergast AJ, Humphrey JH. The stunting syndrome in developing countries. Paediatr Int Child Health 2014;34:250-65.

3. Mehta NM, Corkins MR, Lyman B, et al. Defining pediatric malnutrition: a paradigm shift towards etiology-related definitions. JPEN J Parenter Enteral Nutr 2013;37:460-81.

4. Bhutia DT. Protein energy malnutrition in India: the plight of our under five children. J Family Med Prim Care 2014;3:63-7.

5. Grummer-Strawn LM, Reinold C, Krebs NF, Centers for Disease Control and Prevention. Use of World Health Organization and CDC growth charts for children aged 0-59 months in the United States. MMWR Recomm Rep 2010;59:1-15.

6. Nouri Saeidlou S, Babaei F, Ayremlou P. Malnutrition, overweight, and obesity among urban and rural children in north of west Azerbijan, Iran. J Obes 2014;2014: 541213.

7. World Health Organization (WHO). The WHO child growth standards. Geneva: WHO; 2006.

8. Al Nofal A, Schwenk WF. Growth failure in children: a symptom or a disease? Nutr Clin Pract 2013;28:651-8.

9. Turkey Demographic and Health Survey 2008 (TDHS-2008). Hacettepe University Institute of Population Studies, Ministry of Health General Directorate of Mother And Child Health and Family Planning. T. R. Prime Ministry Undersecretary of State Planning Organization and TÜB TAK, Ankara, Turkey; 2009. Available from: http://www.hips.hacettepe.edu.tr/eng/tdhs 08/TDHS-2008_Main_Report.pdf

10. Aslan D, Özcebe H, Bilir N, et al. Van ili kent merkezinde be ya altı çocuklarda beslenme ve malnütrisyon durumu. Çocuk Dergisi 2004;4:16-23.

11. Ergin F, Okyay P, Atasoylu G, Be er E. Nutritional status and risk factors of chronic malnutrition in children under five years of age in Aydin, a western city of Turkey. Turk J Pediatr 2007;49:283-9.

12. Das SK, Chisti MJ, Malek MA, et al. Changing childhood malnutrition in Bangladesh: trends over the last two decades in urban-rural differentials (19932012). Publ Health Nutr 2015;9:1-10.

13. Rollet SR, Gray ES, Previl H, Forrester JE. 
Prevalence of malnutrition in children under five and school-age children in Milot Valley, Haiti. Public Health 2014;128:1094-8.

14. Manjunath R, K JK, Kulkarni P, et al. Malnutrition among under-five children of kadukuruba tribe: need to reach the unreached. J Clin Diagn Res 2014;8:JC014.

15. Abubakar A, Uriyo J, Msuya SE, et al. Prevalence and risk factors for poor nutritional status among children in the Kilimanjaro region of Tanzania. Int $\mathrm{J}$ Environ Res Public Health 2012;9:3506-18.

16. Müller 0, Krawinkel M. Malnutrition and health in developing countries. CMAJ 2005;173:279-86.

17. Stevens GA, Finucane MM, Paciorek CJ, et al. Trends in mild, moderate, and severe stunting and underweight, and progress towards MDG 1 in 141 developing countries: a systematic analysis of population representative data. Lancet 2012;380:82434.
18. Jiang Y, Su X, Wang C, et al. Prevalence and risk factors for stunting and severe stunting among children under three years old in mid-western rural areas of China. Child Care Health Dev 2015;41:4551.

19. Payandeh A, Saki A, Safarian M, et al. Prevalence of malnutrition among preschool children in northeast of Iran, a result of a population based study. Glob J Health Sci 2013;5:208-12.

20. Kavosi E, Hassanzadeh Rostami Z, Kavosi $\mathrm{Z}$, et al. Prevalence and determinants of under-nutrition among children under six: a cross-sectional survey in Fars province, Iran. Int J Health Policy Manag 2014;3:716.

21. Hossein-nezhad A, Holick MF. Vitamin D for health: a global perspective. Mayo Clin Proc 2013;88:720-55.

22. Wong HJ, Moy FM, Nair S. Risk factors of malnutrition among preschool children in Terengganu, Malaysia: a case control study. BMC Public Health. 2014;14:785.
23. Cole TJ, Flegal KM, Nicholls D, Jackson AA. Body mass index cut offs to define thinness in children and adolescents: internationalsurvey. BMJ 2007;335:194.

24. Ramachandran P, Gopalan HS. Assessment of nutritional status in Indian preschool children using WHO 2006 Growth Standards. Indian J Med Res 2011;134:4753 .

25. Fenton TR, Kim JH. A systematic review and meta-analysis to revise the Fenton growth chart for preterm infants. BMC Pediatr 2013;13:59.

26. Trachtenbarg DE, Golemon TB. Care of the premature infant: part I. Monitoring growth and development. Am Fam Physician 1998;57:2123-30.

27. Mukhopadhyay K, Louis D, Mahajan G, Mahajan R. Longitudinal growth and postdischarge mortality and morbidity among extremely low birth weight neonates. Indian Pediatr 2014;51:723-6. 